\title{
Fiscal Multipliers in the Euro Area
}

\author{
Pablo Burriel, Francisco de Castro, Daniel Garrote, Esther Gordo, Joan Paredes y \\ Javier J. Pérez
}

Revista de Economía y Estadística, Cuarta Época, Vol. 48, No. 2 (2010), pp. 7-27.

http://revistas.unc.edu.ar/index.php/REyE/article/view/4105

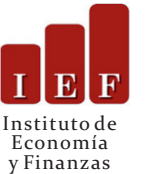

La Revista de Economía y Estadística, se edita desde el año 1939. Es una publicación semestral del Instituto de Economía y Finanzas (IEF), Facultad de Ciencias Económicas, Universidad Nacional de Córdoba, Av. Valparaíso s/n, Ciudad Universitaria. X5000HRV, Córdoba, Argentina.

Teléfono: 00 - 54 - 351 - 4437300 interno 253.

Contacto: rev eco estad@eco.unc.edu.ar

y Finanzas

Dirección web http://revistas.unc.edu.ar/index.php/REyE/index

Cómo citar este documento:

Burriel, P., de Castro F., Garrote D., Gordo E., Paredes J. y Pérez J. (2010). Fiscal Multipliers in the Euro Area. Revista de Economía y Estadística, Cuarta Época, Vol. 48, No. 2 (2010), pp. 7-27.

Disponible en: <http://revistas.unc.edu.ar/index.php/REyE/article/view/4105>

El Portal de Revistas de la Universidad Nacional de Córdoba es un espacio destinado a la difusión de las investigaciones realizadas por los miembros de la Universidad y a los contenidos académicos y culturales desarrollados en las revistas electrónicas de la Universidad Nacional de Córdoba. Considerando que la Ciencia es un recurso público, es que la Universidad ofrece a toda la comunidad, el acceso libre de su producción científica, académica y cultural.

http://revistas.unc.edu.ar/index.php/index

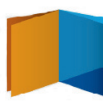




\title{
Fiscal Multipliers in the Euro Area*
}

\author{
Pablo Burriel
}

Research Department, Bank of Spain

Francisco de Castro

Research Department, Bank of Spain

Daniel Garrote

Research Department, Bank of Spain

\section{Esther Gordo}

Research Department, Bank of Spain

\section{Joan Paredes}

Fiscal Policies Division, European Central Bank

\section{Javier J. Pérez}

Research Department, Bank of Spain

\begin{abstract}
In a standard linear structural VAR framework we analyse the size and sign of fiscal multipliers in the euro area, using a newly available quarterly dataset of fiscal variables for the period 1981-2007. From a policy perspective, the analysis of fiscal multipliers in "average times" provides insights on the impact of both fiscal stimulus and fiscal consolidation measures, provided "good" and "bad" times are on average similar.

* The views expressed in this paper are those of the authors and do not necessarily reflect those of the European Central Bank, the Bank of Spain or the Eurosystem. We thank Pablo Hernández de Cos, Ad van Riet, Michele Lenza, seminar participants at the Bank of Spain, the ECB, the Working Group of Public Finance (WGPF) and Banca d'Italia Perugia Workshop, as well as an anonymous referee for useful comments.

Contact details: Pablo Burriel (pburriel@bde.es), Francisco de Castro (fcastro@bde.es), Daniel Garrote (daniel.garrote@bde.es), Esther Gordo (egordo@bde.es) and Javier J. Pérez (javierperez@ bde.es): all Research Department, Bank of Spain. Joan Paredes (joan.paredes@ecb.int), Fiscal Policies Division, European Central Bank.
\end{abstract}


Key words: Euro area; SVAR; Fiscal Shocks; Fiscal multipliers.

JEL Classification: E62; H30.

\section{RESUMEN}

Por medio de un modelo VAR estructural lineal estándar, se analiza la magnitud y el signo de los multiplicadores fiscales para la zona euro, utilizando una base de datos trimestrales de variables fiscales para el periodo 1981-2007 recientemente disponible. Desde una perspectiva política, el análisis de los multiplicadores fiscales en "tiempos normales" proporciona información detallada sobre el impacto tanto de medidas de estímulo fiscal y medidas de consolidación fiscal, a condición de que los periodos "buenos" y "malos" sean en promedio similares.

Palabras clave: Area Euro; SVAR; Shocks Fiscales; Multiplicadores Fiscales.

Clasificación JEL: E62; H30.

\section{INTRODUCTION}

The discussion on the negative impact of fiscal consolidation measures is nowadays extremely topical, as it was slightly more than half a year ago the symmetric discussion on the positive impact of discretionary fiscal measures to stimulate the economic activity implemented to soften the economic downturn. Indeed, by June 2009 almost all OECD economies and many emerging countries had announced or implemented some sort of fiscal stimulus packages. In the case of European economies, the European Commission launched at the end of 2008 the "European Economic Recovery Plan" (EERP), aimed at providing a coordinated fiscal stimulus for the European Union (EU) as a whole. Since the end of 2009 in some countries and more widespread in the course of 2010, the case for fi scal stimulus has turned into the case forfi scal consolidation.

The quantification of the potential negative effects of contractionary fiscal measures on the economy is now crucial. At first sight, given the quasi-agreement of both international organizations and academic economists on the beneficial effects of fiscal stimulus, one may guess that the symmetric policy should depress output.

At the current juncture, the economic impact of fiscal packages remains uncertain. This is certainly the case for the euro area, given the scarcity of relevant studies. Given the single monetary policy in the euro area since 1999 , and the synchronization of monetary policies already since the 
beginning of the 1990's among core euro area countries, the aggregate analysis of fiscal policy shocks for the area as a whole is a pertinent endeavour. Even though fiscal policy has been a country-specific issue over the last two decades, ${ }^{1}$ the use of historical data in euro area wide models is of practical relevance for policy makers. ${ }^{2}$ And given the potential importance of spillover effects of fiscal policy in a highly integrated area such as the EMU, the results available for some specific countries ${ }^{3}$ do not necessarily provide a good guidance for analysing the macroeconomic impact of fiscal shocks in the euro area as a whole.

Thus, the main aim of this paper is to assess the impact of fiscal policy shocks in a (weighed) representative euro area country (the euro area aggregate) on inflation and GDP, the key macroeconomic variables of interest for the ECB. We focus on the sample 1981-2007. ${ }^{4}$

Along the lines of the most recent and standard strand of the literature that started with Blanchard and Perotti (2002), the effects of fiscal policy shocks area assessed within a SVAR framework where identification of fiscal policy shocks is achieved by exploiting decision lags in policy making and information about the elasticity of fiscal variables to economic activity. Along the lines of our broader study Burriel et al. (2010), we focus on a standard methodology for comparability with previous results for other areas/countries. Thus, we aim at capturing the average impact of fiscal policies on GDP. Clearly, our analysis leaves aside the likely non-linear responses of consumers to changes in policies and differences in the extant policy regime

1. This has been the case even under the operation of the Stability and Growth Pact, the fiscal policies' coordination agreement in place in the EU since 1999.

2. See, for instance, Smets and Wouters (2003, 2005), Fagan et al. (2005), Christoffel et al. (2008) and Ratto et al. (2009).

3. For euro area country studies see Heppke-Falk et al. (2006) for Germany, de Castro (2006) and de Castro and Hernández de Cos (2008) for Spain, Giordano et al. (2007) for Italy, Marcellino (2006) for the four largest countries of the euro area or Afonso and Sousa (2009a, 2009b) for Germany, Italy and Portugal, and Bénassy-Quéré and Cimadomo (2006) and Beetsma and Giuliodori (2009) for a group of EU countries. On different grounds, Jacobs et al. (2007) incorporate a fiscal closure rule in a VAR for the euro area.

4. The scarcity of results analysing the impact of fiscal shocks for the euro area as a whole and the countries thereof, is ultimately due to the lack of quarterly data for the general government sector. In fact, until very recently, official data following national accounts conventions for the EMU and the countries comprising it, covering a wide set of variables, were only available in nonseasonally adjusted terms for the period 1999Q1 onwards. This limitation has been recently overcome by Paredes et al. (2009) that provide a quarterly fiscal database for the euro area aggregate for the period 1980Q1-2007Q4. The raw ingredients they use are closely linked to the ones used by national statistical agencies to provide their best estimates (intra-annual fiscal data, mostly on a cash basis), and they preserve full coherence with official, annual data. 
(periods of expansionary fiscal policy vs periods of fiscal consolidation under fiscal stress) that might turn out to be crucial to rationalize the impact of fiscal policies in "good" and "bad" times.

We find for the euro area standard qualitative responses of GDP and inflation to government spending and net-tax shocks. Our results are within the standard ranges of results obtained in similar empirical studies for the US and euro area countries. ${ }^{5}$ To make it short: expansionary fiscal shocks do have a short-term positive impact on GDP and private consumption, with government spending shocks entailing, in general, higher effects on economic activity than (net) tax reductions.

The rest of the paper is organised as follows: section 2 describes the data, section 3 methodological issues and section 4 the results. Finally, we present some concluding remarks in section 5.

\section{The DATA}

As in Blanchard and Perotti (2002) and Perotti (2004), the baseline VAR estimated in this paper includes quarterly data on public expenditure $\left(g_{t}\right)$, net taxes $\left(t_{t}\right)$ and GDP $\left(y_{t}\right)$, all in real terms, ${ }^{6}$ the GDP deflator $\left(p_{t}\right)$ and the ten-year interest rate of government bonds $\left(r_{t}\right)^{7}$ All variables are seasonally adjusted and enter in logs except the interest rate, which enters in levels.

The definition of fiscal variables follows Blanchard and Perotti (2002). In particular, government spending $\left(g_{t}\right)$ is defined as the sum of government consumption and investment, while net taxes $\left(t_{t}\right)$ are defined as total government current receipts, less current transfers and interest payments on government debt. ${ }^{8}$ The reason for this grouping is that government spending on goods and services might have different effects, as it affects directly the aggregate demand of the economy, while transfers and taxes exert their effects through real disposable income that could be partially saved. These definitions have become commonplace in the most recent empirical literature. Given this definitions, the general government primary balance is

5. For a discussion on fiscal multipliers in simulation models see Cwik and Wieland (2009) and Cogan et al. (2009).

6. In all cases the GDP deflator is employed so as to obtain the corresponding real values.

7. The long-term interest rate is preferred to the short-term one because of its closer relationship with private consumption and investment decisions. However, this choice turned out to be immaterial to the results in that the inclusion of short-term rates in the VAR led to similar conclusions.

8. More concretely, transfers include all expenditure items except public consumption, public investment and interest payments. 
obtained as the difference between the levels of $t_{t}$ and $g_{t}$. We use data covering the period 1981:Q1 to 2007:Q4.

Fiscal data have been taken from a newly available quarterly fiscal data set compiled by Paredes et al. (2009). They employ intra-annual fiscal data, mostly on a cash basis, in a mixed-frequencies state space model to obtain quarterly fiscal data for the aforementioned period. These data ensure consistency with annual and quarterly national accounts data where available. The main advantage of the new Paredes et al. (2009) data set is that it avoids the endogenous bias that arises if fiscal data interpolated on the basis of general macroeconomic indicators were used with macroeconomic variables to assess the impact of fiscal policies. These variables are seasonally adjusted according to the statistical model used to draw the corresponding quarterly data. ${ }^{9}$ Other macroeconomic data for the euro area are taken from ECB's Area Wide Model Database (see Fagan et al., 2005).

\section{THE (S)VAR MODEL}

\section{III.1. Specification}

We apply the structural vector autoregressive approach proposed by Blanchard and Perotti (2002) and Perotti (2004). The basic point in this approach is that identification of fiscal policy shocks is achieved by exploiting decision lags in policy making and information about the elasticity of fiscal variables to economic activity.

The reduced-form VAR is specified in levels and can be written as

$$
X_{t}=D(L) X_{t-1}+U_{t}
$$

where $X_{t} \equiv\left(g_{t}, t_{t}, y_{t}, p_{t}, r_{t}\right)$ is the vector of endogenous variables and $D(L)$ is an autoregressive lag polynomial. The benchmark specification includes a constant term, but no deterministic time trends. The vector $U_{t} \equiv\left(u_{t}^{g}, u_{t}^{t}, u_{t}^{y}, u_{t}^{p}, u^{r}\right)$ contains the reduced-form residuals, which in general will present non-zero cross-correlations. The VAR includes two lags of each endogenous variable according to the information provided by LR tests, the Akaike, Schwarz and Hannan-Quinn information criteria and the final prediction error. ${ }^{10}$

9. Another alternative would consist in using TRAMO-SEATS (see Gómez and Maravall, 1996) to extract the seasonal component.

10. In order to assess the robustness of our results to different specifications and transformations, we tried several alternatives, including estimating with variables in per capita terms, adding 


\section{III.2. Identification strategy}

The reduced-form residuals have little economic significance in that they are linear combinations of structural shocks. In particular, the reducedform residuals of the $g_{t}$ and $t_{t}$ equations, $u_{t}^{g}$ and $u_{t}^{t}$ can be thought of as linear combinations of three types of shocks: a) The automatic responses of spending and net taxes to GDP, price and interest rate innovations, b) systematic discretionary responses of fiscal policy to the macro variables in the system (for instance, reductions in tax rates that some countries could implement systematically in response to recessions), and c) random discretionary fiscal policy shocks, which are the truly uncorrelated structural fiscal policy shocks. Thus, from (1) the reduced-form residuals in the first two equations can be expressed as:

$$
u_{t}^{g}=\alpha_{g, y} u_{t}^{y}+\alpha_{g, p} u_{t}^{p}+\alpha_{g, r} u_{t}^{r}+\beta_{g, t} e_{t}^{t}+e_{t}^{g}
$$

and

$$
u_{t}^{t}=\alpha_{t, y} u_{t}^{y}+\alpha_{t, p} u_{t}^{p}+\alpha_{t, r} u_{t}^{r}+\beta_{t, g} e_{t}^{g}+e_{t}^{t}
$$

where $e^{g}{ }_{t}$ and $e_{t}^{t}$ are the "structural" discretionary fiscal shocks. As we are interested in analysing the effects of $e^{g}{ }_{t}$ and $e_{t}^{t}$, on the rest of the variables of the system, estimations for the $\alpha_{i, j}$ 's and $\beta_{i, j}$ 's in (2) are needed.

The approach we follow here is based on Blanchard and Perotti (2002). The key to this approach is the observation that approving and implementing new measures in response to innovations in the main macroeconomic variables typically takes longer than three months. Hence, the use of quarterly variables allows for setting the discretionary contemporaneous response of government expenditure or net taxes to GDP, prices or interest rate innovations to zero. Therefore, the coefficients $\alpha_{i, j}$ 's in (2a) and (2b) only reflect the automatic responses of fiscal variables to innovations in the rest of the variables of the system, the first component aforementioned, and they can be estimated using institutional information on the elasticity of taxes and spending to GDP, prices and the interest rate. In particular, given that interest payments on government debt are excluded from the definitions of expenditure and net taxes, the semi-elasticities of these two fiscal variables to interest rate innovations, i.e. $\alpha_{g, r}$ and $\alpha_{t, r}$, are set to zero. While this

a time trend, allowing for four lags instead of two and substituting the long-term interest rate by a short-term one. These different alternatives showed broadly the same qualitative results and are available upon request. 
assumption appears justified for government expenditure and plays no role when analysing its effects, it is slightly more controversial for net taxes. ${ }^{11}$

Consider now equation (2a). Our choice of the items included in the definition of government expenditure, notably public consumption and investment, makes it hard to think about any automatic response of public expenditure to economic activity. Accordingly, we can set $\alpha_{g, y}=0$. The case of the price elasticity is different, though. Some share of purchases of goods and services is likely to respond to the price level. In addition, the wage component is typically indexed (either formally or via ex-post adjustements) to the CPI, even though indexation takes place with some delay. Thus, we adopted the same eclectic approach as in Perotti (2004), according to which the price elasticity of government expenditure was set to -0.5 .

The output and price elasticities $\alpha_{i, j}$ in (2b) are weighted averages of the elasticities of the different net-tax components, including transfers, computed on the basis of information like statutory tax rates and estimations of the contemporaneous responses of the different tax-bases and, in the case of transfers, the relevant macroeconomic aggregate to GDP and price changes. In general, contemporaneous output elasticities of net taxes can be calculated as:

$$
\alpha_{t, y}=\sum_{i} \varepsilon_{T_{i}, B_{i}} \varepsilon_{B_{i}, y} \frac{T_{i}}{T}
$$

with $T=\sum T_{i}$ being the level of net taxes, ${ }^{12} \varepsilon_{T i, B i}$ the elasticity of the $\mathrm{i}^{\text {th }}$ category of net taxes to its own tax base and $\varepsilon_{B i, y}$ the GDP elasticity of the tax base of the $i^{\text {th }}$ category of net taxes. Price elasticities for some components of net taxes were, however, obtained directly by econometric estimation, whereas others were calibrated.

According to our estimations, output elasticity is 1.54, whereas price elasticity amounts $1.14 .^{13}$ These elasticities are similar to those obtained in previous papers. For instance, Perotti (2004) gauges an output elasticity of 1.97 for the USA (for the subsample 1980-2000), while the price elasticity is set to 1.4. There are no reference values for the euro area though. The closer

11. In many cases, the income tax base includes interest income as well as dividends, which in general co-vary negatively with interest rates. Nevertheless, the full set of effects of interest rate innovations on the different tax categories are very complex to analyse and, on the other hand, their contemporaneous effects are deemed to be very small.

12. The $T_{i}$ 's are positive in the case of taxes and negative in the case of transfers.

13. Table A1 provides further details about the different elasticities behind these aggregate output and price elasticities. 
available results would be those for Germany, estimated at 0.72 and 0.98 in Heppke-Falk et al. (2006). The higher euro area results compared to Germany might indicate, among other factors, the presence of cross-country spill-over effects that potentially lead to higher multipliers than at the national level.

Once output and price elasticities have been estimated, the so-called "adjusted" fiscal shocks $\left(u^{C A}\right)$ can be derived as follows:

$$
\begin{aligned}
& u_{t}^{g, C A}=u_{t}^{g}-\left(\alpha_{g, y} u_{t}^{y}+\alpha_{g, p} u_{t}^{p}+\alpha_{g, r} u_{t}^{r}\right)=\beta_{g, t} e_{t}^{t}+e_{t}^{g} \\
& u_{t}^{t, C A}=u_{t}^{t}-\left(\alpha_{t, y} u_{t}^{y}+\alpha_{t, p} u_{t}^{p}+\alpha_{t, r} u_{t}^{r}\right)=\beta_{t, g} e_{t}^{g}+e_{t}^{t}
\end{aligned}
$$

As mentioned in Perotti (2004), there is little guidance, theoretical or empirical, on how to identify the two structural shocks in (3a) and (3b), We assume that expenditure decisions are prior to tax ones, which implies a zero value for $\beta_{g, t}$. This allows us to retrieve $e^{g}$ directly from (3a) and to use it in (3b) in order to estimate $\beta_{t, g}$ by OLS. ${ }^{14}$ Since we are interested in studying the effects of fiscal policy shocks, the ordering of the remaining variables is immaterial to the results. Accordingly, the reduced-form output residuals are assumed to be a linear combination of the fiscal shocks.

$$
u_{t}^{y}=\gamma_{y, g} u_{t}^{g}+\gamma_{y, t} u_{t}^{t}+e_{t}^{y}
$$

By defi nition, some contemporaneous correlation between the reduced-form residuals of the fiscal equations and $e^{y}{ }_{t}$ is expected. Hence (4) is estimated by instrumental variables, using the structural uncorrelated fiscal shocks $e_{t}^{g}$ and $e_{t}^{t}$ as instruments for $u_{t}^{g}$ and $u_{t}^{t}$, respectively. Likewise, the coefficients of $\Gamma$ corresponding to the price and interest rate equations can be obtained in turn in a similar way.

The innovations model can be written as $\Gamma U_{t}=\mathrm{B} V_{t}$, where $V_{t} \equiv\left(e_{t}^{g} e_{t}^{t}\right.$, $\left.e_{t}^{v}, e_{t}^{p}, e_{t}^{r}\right)$ is the vector containing the orthogonal structural shocks. The respective matrixes $\Gamma$ and $\mathrm{B}$ can be written as

14. As shown in Perotti (2004), the correlation between the two cyclically adjusted fiscal shocks is very low, so the ordering is immaterial for the results. 


$$
\Gamma=\left(\begin{array}{ccccc}
1 & 0 & -\alpha_{g, y} & -\alpha_{g, p} & -\alpha_{g, r} \\
0 & 1 & -\alpha_{t, y} & -\alpha_{t, p} & -\alpha_{t, r} \\
-\gamma_{y, g} & -\gamma_{y, t} & 1 & 0 & 0 \\
-\gamma_{p, g} & -\gamma_{p, t} & -\gamma_{p, y} & 1 & 0 \\
-\gamma_{r, g} & -\gamma_{r, t} & -\gamma_{r, y} & -\gamma_{r, p} & 1
\end{array}\right)
$$

and

$$
\mathrm{B}=\left(\begin{array}{ccccc}
1 & \beta_{g, t} & 0 & 0 & 0 \\
\beta_{t, g} & 1 & 0 & 0 & 0 \\
0 & 0 & 1 & 0 & 0 \\
0 & 0 & 0 & 1 & 0 \\
0 & 0 & 0 & 0 & 1
\end{array}\right)
$$

Accordingly, the reduced-form residuals are linear combinations of the orthogonal structural shocks of the form $U_{t}=\Gamma^{-1} \mathrm{~B} V_{t}$.

\section{III.3. Possible weaknesses of the SVAR approach to model fiscal policy shocks}

One frequent criticism to the identification of quarterly fiscal policy shocks is that fiscal decisions are mainly taken on a year-by-year basis as embedded in the budget. However, while acknowledging that the yearly budget incorporates important policy measures, supplements to it and other decisions affecting fiscal policy during the year are always possible and, indeed, have been commonplace in most of the sample period under consideration.

Another important criticism relates to implementation lags, i.e the typical long lag between the announcement of a fiscal measure, and the time the measure is actually adopted. Under rational expectations, economic agents adjust their decisions on consumption, saving and labour supply as soon as they have information on future changes in fiscal policy. If this is the case, the VAR-based estimated effects on the basis of quarterly data might be biased, although the sign of the bias is not clear. In particular, Ramey (2007) finds that failing to account for the anticipation effect causes the SVAR to capture shocks too late, missing some non-keynesian effects of fiscal policy (the initial decline in consumption that occurs as the news is known). By contrast, Blanchard and Perotti (2002) and Heppke-Falk et al. (2006) try to address this criticism including an indicator of future fiscal policy measures in their estimation procedure, finding qualitatively similar results. Perhaps, the existence of liquidity constrains or the presence of shortsighted consumers might reduce the significance of the announcement 
effect. Leeper et al. (2008) analyse the difficulties that fiscal foresight introduces in the estimation and interpretation of conventional analyses of fiscal shocks; even though they show that not accounting for anticipation effects might distort the interpretation of net taxes' shocks, ${ }^{15}$ they also hint that under certain circumstances foresight might not impinge on the identification of other shocks, like government spending shocks. However, Yang (2007) argues that including lagged interest rates and prices leads to lower responses to tax shocks in that lagged interest rates and prices contain information about macroeconomic variables related to current tax changes. Thus, the inclusion of prices and interest rate in our VAR might help assuage the foresight problem.

Finally, Favero and Giavazzi (2007) argue that the omission of public debt in the VAR leads to biased results as they fail to take into account the debt dynamics that arises after a fiscal shock and, more importantly, overlook the possibility of taxes and spending responding to the level of debt. We address this issue and include debt (changes in debt) in a similar way as Favero and Giavazzi in Burriel et al. (2010).

\section{THE EFFECTS OF GOVERNMENT SPENDING AND TAX SHOCKS}

\section{IV.1. Interpreting the fiscal shocks}

Figure 1 represents the fiscal shocks that we estimate in our baseline VAR for the EMU. In general, the largest fiscal shocks tend to be associated with episodes of discretionary government actions. Beginning with spending, negative shocks in public spending are found throughout the period 1994-1997 related to the fiscal consolidation episodes previous to the euro adoption, as the decision whether or not a country entering EMU was taken on the basis of the fiscal deficit recorded in 1997. We identify also positive shocks in 1990-1991 associated with the German reunification process that was followed by a significant increase in public spending. In the case of net revenue, we estimate positive residuals along the years 1995-1997, related also to the fiscal consolidation process previous to the EMU accession. 
Figure 1

\section{Estimated shocks to fiscal variables}
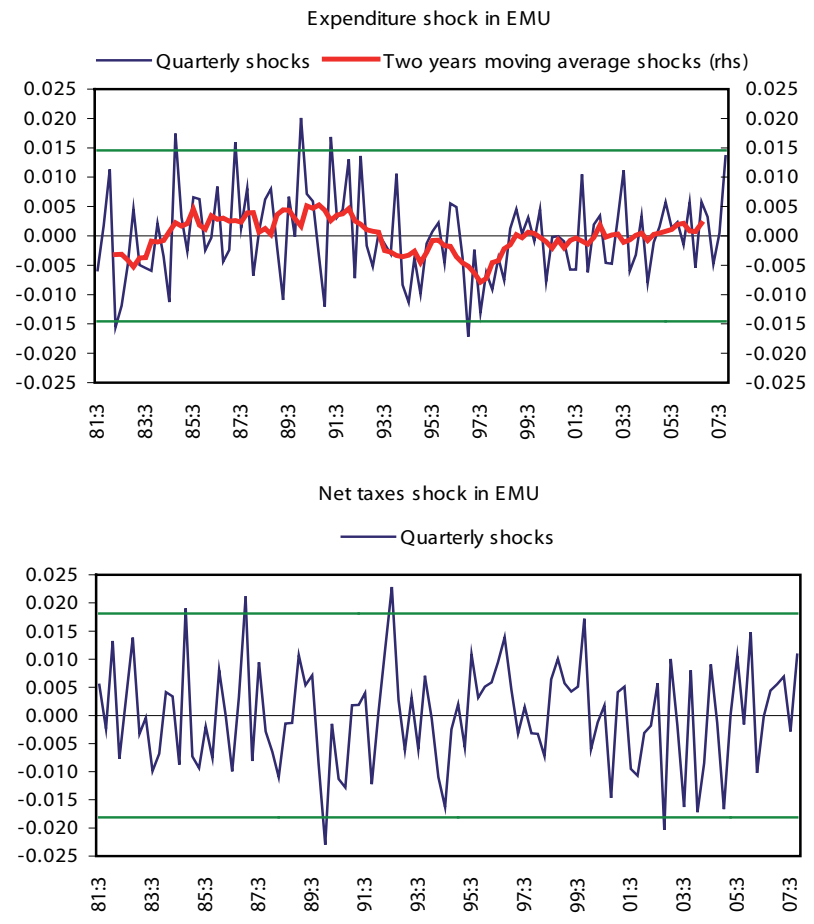

The lines indicate the one standard deviation band width.

\section{IV.2. The baseline VAR}

Figure 2 displays the responses of the endogenous variables to a positive expenditure shock. ${ }^{16}$ Firstly, after a spending shock, GDP increases and remains significant for five quarters, becoming non-significant thereafter. This result is largely in line with previous evidence for the US and other countries. In general, government spending shocks are found to yield positive output responses in the short-term (Perotti, 2004; Neri, 2001; Mountford and Uhlig, 2009), although the size and persistence of output multipliers varies significantly across studies. ${ }^{17}$

16. Impulse responses show deviations with respect to the baseline to a one-percent shock of the relevant fiscal variable. Hence, GDP responses cannot be directly interpreted as output multipliers.

17. Caldara and Kamps (2008) show that, after controlling for differences in the specification of the reduced form model, all identification approaches used in the literature yield qualitatively and 
As for the impact of a government spending shock on the other variables in the system, prices increase with respect to the baseline, leading to a hump-shaped response of inflation. Despite being a rather intuitive and, on the other hand, expected result, previous evidence is far from conclusive. For example, Fatás and Mihov (2001) and Mountford and Uhlig (2009) find negative effects on prices and inflation, whereas in the case of Marcellino (2006) the impact found is not significant in the case of Germany, Spain and Italy and positive in the case of France. In turn, Perotti (2004) reports mixed evidence depending on the country and period under consideration. Likewise, the long-term interest rate rises in response to the shock and remains significant for more than 2 years. ${ }^{18}$

Cumulative multipliers ${ }^{19}$ to expenditure shocks are shown in Table Output multipliers are rather low, slightly below 1 in the first year following the shock, diminishing thereafter and becoming non-significant from the third year onwards. Such low multipliers are indicative of sizeable crowding-out effects.

On the other hand, our output multipliers are significantly larger than those reported in Perotti (2004) for the US, using a sample covering the period 1980-2000. However, if our sample period is restricted until 2000, we obtain multipliers for the EMU very similar to those obtained by Perotti. Thus, our larger output multipliers seem to be due to what has happened between 2000 and 2007. Actually, Figure 3 shows that recursive output multipliers have increased steadily since 2000 , especially at the $4^{\text {th }}$ and $8^{\text {th }}$ quarters after the shock. The cause of this result may be related to the "global saving glut" which might have caused a decrease in global risks premia, diminishing the crowding-out effects of fiscal policy on private investment. ${ }^{20}$ However, this fact remains an open question that might deserve further research in the future.

quantitatively very similar results for government spending shocks. By contrast, they find strongly diverging results for the effects of tax shocks. These differences stem from differences in the size of the automatic stabilisers estimated or calibrated under alternative identification approaches.

18. In the literature, the impact of expansionary government spending shocks on interest rates tends to be positive, although rather small (see for instance Perotti, 2004).

19. The cumulative multiplier at a given quarter is obtained as the ratio of the cumulative response of GDP and the cumulative response of government expenditure at that quarter.

20. Laubach (2009) analyses the effects of public deficits and debt on interest rates and finds that the relationship between deficits and interest rates turns from positive to negative in the period after 1999:Q1. 
Figure 2

Responses to an increase in government spending
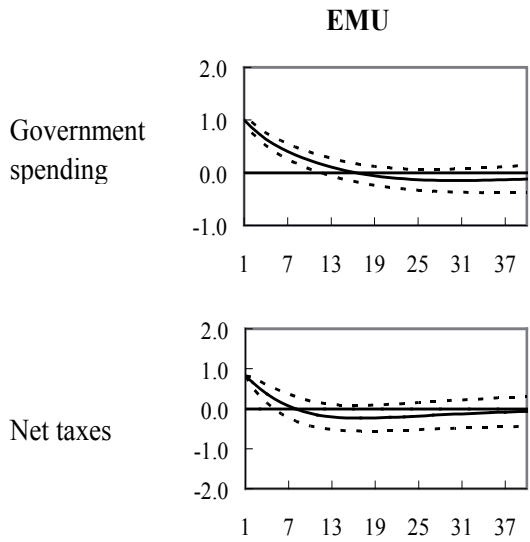

GDP

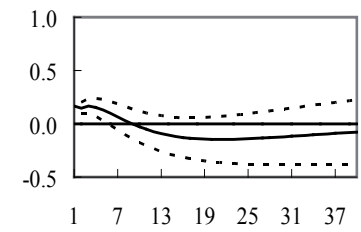

Prices
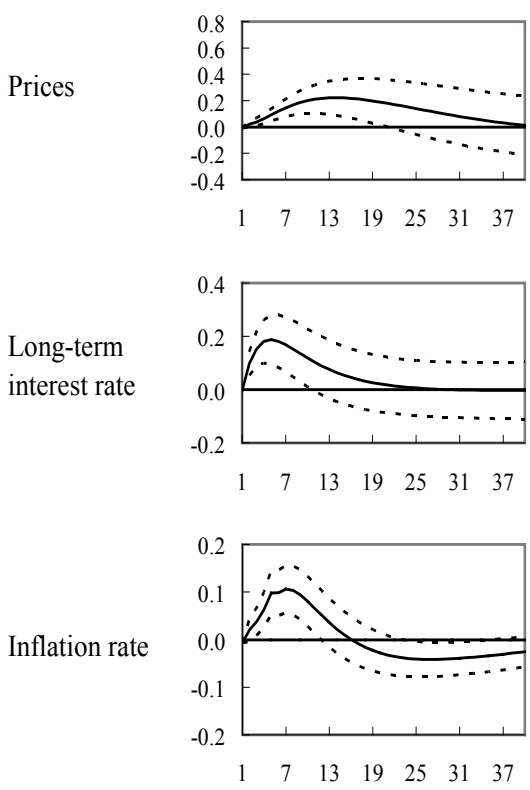
Table 1

Cumulative output multipliers

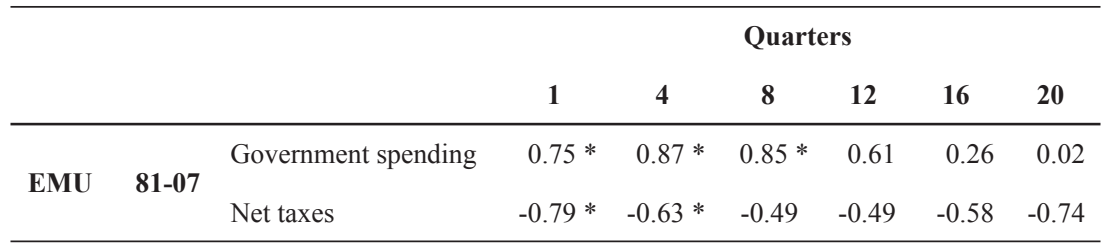

Note: the asterisks indicate significance within the one-standard deviation band-width.

Figure 3

Recursive output multipliers to government spending shocks

EMU

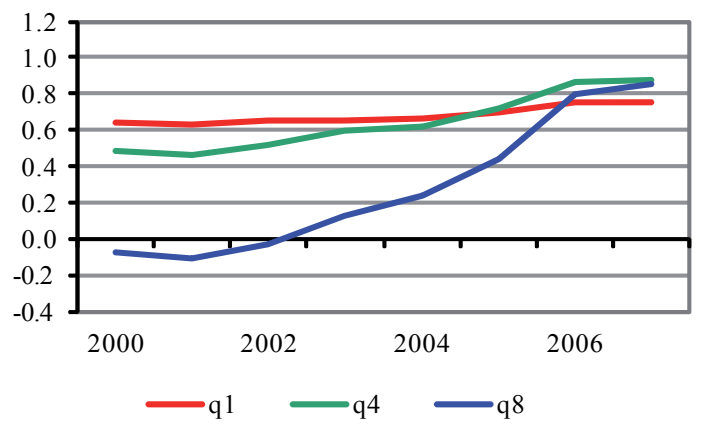

The responses to net-tax shocks are depicted in Figure 4. Specifically, GDP falls on impact in response to net-tax increases in the EMU, but the GDP response remains significant for only three quarters. Likewise, prices, and consequently inflation, fall in the quarters following the shock, presumably due to lower demand pressures and interest rates fall on impact, although the response become non-significant three quarters after the shock. Finally, government expenditure eventually falls. In turn, output multipliers turn out to be negative and lower in absolute value than government spending output multipliers when significant (see again Table 1).

As in the case of spending shocks, these results are qualitatively similar to the findings in previous studies. In general, many empirical papers find that tax multipliers are lower than spending ones in the short-term, which is consistent with the theoretical prediction that part of the higher disposable income stemming from tax cuts is saved. This is the case in Blanchard and Perotti 
(2002) and Mountfourd and Uhlig (2009). However, some evidence suggests that in the longer term tax multipliers could be higher than spending multipliers. Additional changes in the model specification, alternative variables and a broader sensitivity analysis of the results can be found in Burriel et al. (2010).

Figure 4

Responses to an increase in net taxes

EMU

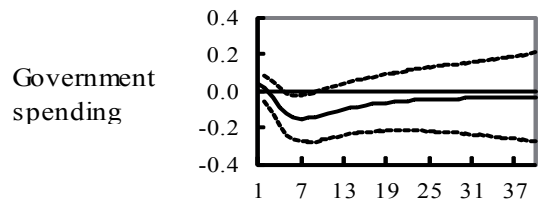

Net taxes

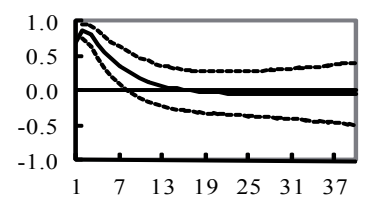

GDP

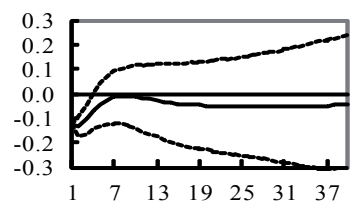

Prices

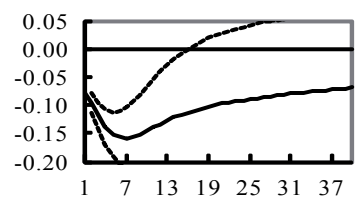

Long-term interest rate

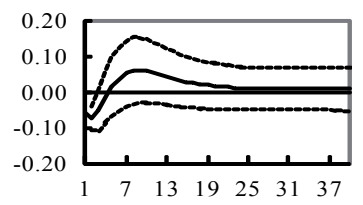

Inflation rate

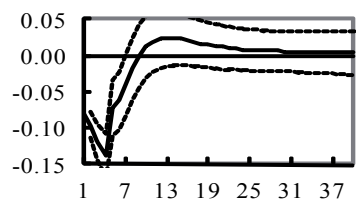




\section{Conclusions}

This paper contributes to previous literature analysing the effects of fiscal policy for the euro area as a whole, employing a new database that contains quarterly fiscal variables.

In line with previous evidence, we find that GDP and inflation increase in response to government spending shocks, although output multipliers are below unity. However, we provide evidence of output multipliers increasing steadily after 2000 in the EMU, possibly related to the "global saving glut". In turn, net-tax increases weight on economic activity, with the negative response being short-lived. In line with previous studies, we find that tax multipliers are lower than spending ones in the short-term.

\section{Appendix A:}

\section{CONSTRUCTION OF OUTPUT AND PRICE ELASTICITIES}

In order to calculate the output and price elasticities we basically follow the OECD methodology proposed in Giorno et al. (1995), which focuses on four tax categories, i.e. personal income tax, corporate income tax, indirect taxes and social security contributions. In addition, they consider the elasticity of transfer programmes, notably unemployment benefits. On this issue, in more general terms see Golinelli and Momigliano (2009) for a survey of the cyclical response of fiscal policies.

According to this methodology, the output elasticity of the personal income tax can be obtained as:

$$
\varepsilon_{\text {tdirh }, y}=\left(\varepsilon_{\text {tdirh }, w} \varepsilon_{w, e m p}+1\right) \varepsilon_{e m p, y}
$$

where $\varepsilon_{\text {tdirh, } w}$ is the elasticity of personal income tax revenues to earnings, measured by the compensation per employee, $\varepsilon_{w, e m p}$ is the employment elasticity of the real wage and $\varepsilon_{e m p, y}$ the GDP elasticity of employment. Analogously, the output elasticity of social security contributions is:

$$
\varepsilon_{s s, y}=\left(\varepsilon_{s s, w} \varepsilon_{w, e m p}+1\right) \varepsilon_{e m p, y}
$$

with $\varepsilon_{s s, w}$ being the elasticity of social contributions to earnings.

The output elasticity of corporate income tax revenues stems from:

$$
\varepsilon_{\text {tdirc }, y}=\varepsilon_{\text {tdirc }, \text { gos }} \varepsilon_{\text {gos }, y}
$$


where $\varepsilon_{\text {tdirc,gos }}$ is the elasticity of tax revenues to the gross operating surplus and $\varepsilon_{\text {gos, } y}$ the output elasticity of the gross operating surplus. In the same fashion, given that the main tax base for indirect tax collections is private consumption, the output elasticity of indirect taxes is obtained as:

$$
\varepsilon_{\text {tind }, y}=\varepsilon_{\text {tind }, c} \varepsilon_{c, y}
$$

where $\varepsilon_{t d i n d, c}$ and $\varepsilon_{c, y}$ are the private consumption elasticity of indirect taxes and the output elasticity of private consumption, respectively.

Since we employ data on a national accounts basis, collection lags should not affect the elasticities to the respective tax-bases significantly. Hence, these have been taken from van den Noord (2000) and Bouthevillain et al. (2001). The output elasticities of the relevant tax bases were, however, obtained from econometric estimation on a quarterly basis. In general, the general equation used for estimating these elasticities was:

$$
\Delta \operatorname{Ln}\left(B_{t}^{i}\right)=\gamma+\varepsilon_{i} \Delta \operatorname{Ln}\left(Y_{t}\right)+\eta_{t}
$$

where $B^{i}$ is the relevant tax base for the $\mathrm{i}^{\text {th }}$ tax category and $\varepsilon_{i}$ is the output elasticity of such tax base. These equations, given the likely contemporaneous correlation between the independent variable and the error term, were estimated by instrumental variables. However, if the variables $B^{i}$ and $Y$ are cointegrated, (A.5) contains a specification error. In this case, the following ECM specification would be preferable:

$$
\begin{aligned}
\Delta \operatorname{Ln}\left(B_{t}^{i}\right)= & \gamma+\mu\left(\operatorname{Ln}\left(B_{t-1}^{i}\right)-\lambda \operatorname{Ln}\left(Y_{t-1}\right)-\phi\right)+\varepsilon_{i} \Delta \operatorname{Ln}\left(Y_{t}\right) \\
& +\sum_{j=1}^{k} \varphi_{j} \Delta \operatorname{Ln}\left(Y_{t-j}\right)+\sum_{j=1}^{k} v_{j} \Delta \operatorname{Ln}\left(B_{t-j}^{i}\right)+\eta_{t}
\end{aligned}
$$

where $\lambda$ measures the long-term contemporaneous elasticity we are interested in.

Information on the output elasticity of net transfers is more limited than in the former cases. Although unemployment benefits respond to the underlying economic conditions, many expenditure programmes do not have built-in conditions that make them respond contemporaneously to employment or output. Therefore, recalling Perotti's argument, an output elasticity of net transfers of -0.2 has been assumed.

As for price elasticities, following van der Noord (2000) the elasticity of direct taxes paid by households, corporate income taxes and social 
contributions were obtained as $\varepsilon_{\text {tdirh }, p}=\varepsilon_{\text {tdirh, },}-1$ (yielding 0.9), $\varepsilon_{\text {tdirc, } p}=\varepsilon_{\text {tdirc,gos }}-1$ (with a value equal to 0 ) and $\varepsilon_{s s, p}=\varepsilon_{s s, w}-1$ (being -0.1), respectively. Indirect taxes are typically proportional. Hence, following Perotti (2004), a zero price elasticity was assumed. Finally, although transfer programmes are indexed to the CPI, indexation occurs with a considerable lag. Thus, the price elasticity of transfers was set to -1 . Table A.1 shows the resulting output and price elasticities.

Table A.1.

Output and price elasticities of net taxes

\begin{tabular}{|c|c|}
\hline & EMU \\
\hline$\overline{\varepsilon_{t d i r h, w}}$ & 2.0 \\
\hline$\varepsilon_{w, e m p}$ & 0.65 \\
\hline$\varepsilon_{e m p, y}$ & 0.39 \\
\hline$\varepsilon_{s S, w}$ & 1.0 \\
\hline$\varepsilon_{t d i r c, g o s}$ & 1.0 \\
\hline$\varepsilon_{g o s, y}$ & 1.08 \\
\hline$\varepsilon_{c, y}$ & 0.97 \\
\hline$\varepsilon_{t i n d, c}$ & 1.0 \\
\hline \multicolumn{2}{|c|}{ Output elasticities } \\
\hline$\varepsilon_{t d i r h, y}$ & 0.90 \\
\hline$\varepsilon_{s s, y}$ & 0.64 \\
\hline$\varepsilon_{t d i r c, y}$ & 1.08 \\
\hline$\varepsilon_{t i n d, y}$ & 0.97 \\
\hline$\varepsilon_{\text {transf,y }}$ & -0.2 \\
\hline$\varepsilon_{t, y}$ & 1.54 \\
\hline \multicolumn{2}{|c|}{ Price elasticities } \\
\hline$\varepsilon_{t d i r, p}$ & 1.0 \\
\hline$\varepsilon_{s s, p}$ & 0.0 \\
\hline$\varepsilon_{t i n d, p}$ & 0.0 \\
\hline$\varepsilon_{\text {transf,p }}$ & -1.0 \\
\hline$\varepsilon_{t, p}$ & 1.14 \\
\hline
\end{tabular}




\section{REFERENCES}

Afonso, A. and R. M. Sousa (2009a). "The macroeconomic effects of fiscal policy”. ECB Working Paper Series No. 991, January.

Afonso, A. and R. M. Sousa (2009b). "The macroeconomic effects of fiscal policy in Portugal: a Bayesian SVAR analysis". School of Economics and Management, Working Papers No 09/2009/DE/UECE.

Bénassy-Quéré, A. and J. Cimadomo (2006). "Changing patterns of domestic and cross-border fiscal policy multipliers in Europe and the US". CEPII WP \#2006-24.

Beetsma, R. and M. Giuliodori (2009). "Discretionary fiscal policy: review and estimates for the EU". Mimeo.

Blanchard, O. J. and R. Perotti (2002). "An Empirical Characterization of the Dynamic Effects of Changes in Government Spending and Taxes on Output". Quarterly Journal of Economics, 117, pp. 1329-1368.

Bouthevillain, C., Cour-Thimann, P., van den Dool, G., Hernández de Cos, P., Langenus, G., Mohr, M., Momigliano, S., Tujula, M., 2001. "Cyclically adjusted budget balances: An alternative approach". ECB Working Paper Series No. 77.

Burriel, P., de Castro, F., Garrote, D., Gordo, E., Paredes, J., Pérez, J., 2010. "Fiscal Policy shocks in the Euro Area and the US: an empirical assessment", Fiscal Studies, 31(2), pp. 251-285.

Caldara, D. and C. Kamps (2008). "What are the effects of fiscal policy shocks? A VAR-based comparative analysis". ECB Working Paper Series No. 877, March.

Cogan, J., T. Cwik, J.B. Taylor and V. Wieland (2009). "New Keynesian versus Old Keynesian Government Spending Multipliers”. CEPR Discussion Paper 7236, March.

Christoffel, K., G. Coenen and A. Warne (2008). "The New Area-Wide Model of the euro area: a micro-founded open-economy model for forecasting and policy analysis”. ECB Working Paper Series No 944, October.

Cwik, T. and V. Wieland, (2009). "Keynesian government spending multipliers and spillovers in the Eurozone". CEPR Discussion Paper 7389, August.

de Castro, F. (2006). "The macroeconomic effects of fiscal policy in Spain". Applied Economics, 38, pp. 913-924. 
de Castro, F. and P. Hernández de Cos (2008). "The economic effects of fiscal policy: the case of Spain. Journal of Macroeconomics”, 30, pp. 1005-1028.

Fatás, A. and I. Mihov (2001). "The effects of fiscal policy on consumption and employment: theory and evidence". CEPR Discussion Paper Series No. 2760.

Fagan, G., J. Henry and R. Mestre (2005). "An area-wide model (AWM) for the euro area. Economic Modelling”, 22, pp. 39-59.

Favero, C, and F. Giavazzi (2007). "Debt and the effects of fiscal policies". NBER Working Paper Series No. 12822.

Giordano, R., S. Momigliano, S. Neri and R. Perotti (2007). "The effects of fiscal policy in Italy: Evidence from a VAR model". European Journal of Political Economy, 23, pp. 707-733.

Giorno, C., P. Richardson, D. Roseveare and P. van den Noord (1995). "Potential output, output gaps and structural budget balances". OECD Economic Studies 24.

Golinelli, R. and S. Momigliano (2009). "The cyclical reaction of fiscal policies in the euro area: the role of modelling choices and data vintages". Fiscal Studies, 30, pp. 39-72.

Gómez, V. and A. Maravall (1996). "Programs TRAMO (Time series Regression with ARIMA noise, Missing observations, and Outliers) and SEATS (Signal Extraction in ARIMA Time Series). Instructions for the User". Working Paper 9628, Banco de España.

Heppke-Falk, K.H., J. Tenhofen and G.B. Wolff (2006). "The macroeconomic effects of exogenous fiscal policy shocks in Germany: a disaggregated SVAR analysis”. Deutsche Bundesbank. Discussion Paper Series 1: Economic Studies No 41/2006.

Jacobs, J. P. A. M., G. H. Kuper and J. Verlinden (2007). "Monetary policy in the euro area: the impact of fiscal closure rules". Working Paper 2007/01, Institute of Economics and Econometrics, University of Groningen.

Laubach, T. (2009). "New evidence on the interest rate effects of budget deficits and debt". Journal of the European Economic Association, 7(4), pp. 858-885. 
Leeper, E.M.. T.B. Walker and S.S. Yang (2008). "Fiscal foresight: analytics and econometrics". NBER Working Paper Series No. 14028.

Marcellino, M. (2006). "Some stylized facts on non-systematic fiscal policy in the euro area". Journal of Macroeconomics, 28, pp. 461-479.

Mountford, A. and H. Uhlig (2009). "What are the effects of fiscal policy shocks?" Forthcoming in the Journal of Applied Econometrics.

Neri, S. (2001). "Assessing the effects of monetary and fiscal policy". Banca d'Italia Discussion Papers No. 425.

Paredes, J., D. J. Pedregal and J. J. Pérez (2009). "A quarterly fiscal database for the euro area based on intra-annual fiscal indicators". ECB Working Paper Series, forthcoming.

Perotti, R. (2004). "Estimating the effects of fiscal policy in OECD countries". Proceedings, Federal Reserve Bank of San Francisco.

Ramey, V. (2007). Comment on "In search of the transmission mechanism of fiscal policy". In: NBER Macroeconomics Annual 2007, Volume 22.

Ratto, M., W. Roeger, and J. in't Veld (2009). “Quest III, An estimated openeconomy DSGE model of the Eurozone with fiscal and monetary policy”. Economic Modelling, 26, pp. 222-233.

Smets, F. and R. Wouters (2003). "An estimated dynamic stochastic general equilibrium model of the euro area". Journal of the European Economic Association, 1, pp. 1123-1175.

Smets, F. and R. Wouters (2005). "Comparing shocks and frictions in US and euro area business cycles: a Bayesian DSGE approach". Journal of Applied Econometrics, 20, pp. 161-183.

van den Noord, P. (2000). "The size and role of automatic fiscal stabilizers in the 1990s and beyond". OECD Working Paper No. 230.

Yang, S.-C.S. (2005). "Quantifying tax effects under policy foresight". Journal of Monetary Economics, 52(8), pp. 1557-1568.

Yang, S.-C.S. (2007). "Tentative evidence of tax foresight". Economics Letters, 96, pp. 30-37. 